\title{
EFEKTIVITAS PELAYANAN TERPADU SATU PINTU DALAM MENINGKATKAN KUALITAS PELAYANAN PUBLIK DI DINAS PENANAMAN MODAL DAN PELAYANAN TERPADU SATU PINTU PROVINSI ACEH
}

\author{
Oleh \\ Rizky Fitriyansyah ${ }^{1}$, \\ Aries Djaenuri2 ${ }^{2}$ Mansyur $^{3}$ \\ 1) Pemerintah Provinsi Aceh \\ Program Magister Terapan Studi Pemerintahan Daerah Institut Pemerintahan Dalam Negeri \\ icik.grazy@gmail.com \\ ${ }^{2,3)}$ Institut Pemerintahan Dalam Negeri
}

\begin{abstract}
$O^{\prime \prime}$ ne Stop Integrated Service is a form of simplification of public services initiated by the Government to improve the quality of public services provided to the community. However, in reality, the implementation of One Stop Services for the Investment Service and One Stop Services for Aceh Province has not been effective in improving the quality of public services. For this reason, this study wants to describe how the effectiveness of One Stop Services in improving the quality of one-stop integrated services at the Investment Service and One Stop Services of Aceh Province.

This research uses descriptive qualitative method with inductive shortening. The technique of collecting data uses interview, documentation, and observation methods

The research findings reveal that the One Stop Integrated Service has not been effective in improving the quality of public services at the Investment Service and One Stop Integrated Services in Aceh Province. As for what causes the ineffectiveness of One Stop Integrated Service in improving the quality of public services is the inadequate quality of human resources, incomplete facilities and infrastructure available, and less than optimal budget management.
\end{abstract}

Keywords: Effectiveness, One Stop Integrated Service, Public Service

\section{Abstrak}

$\mathrm{P}^{\mathrm{s}}$ elayanan Terpadu Satu Pintu merupakan sebuah bentuk penyederhanaan pelayanan publik yang digagas oleh Pemerintah untuk meningkatkan kualitas pelayanan publik yang diberikan kepada masyarakat. Namun kenyataannya, penyelenggaraan Pelayanan Terpadu Satu Pintu Dinas Penanaman Modal dan Pelayanan Terpadu Satu Pintu Provinsi Aceh belum berjalan secara efektif untuk meningkatkan kualitas pelayanan publik. Untuk itu penelitian ini ingin menggambarkan bagaimana efektivitas Pelayanan Terpadu Satu Pintu dalam meningkatkan kualitas pelayanan terpadu satu pintu di Dinas Penanaman Modal dan Pelayanan Terpadu Satu Pintu Provinsi Aceh.

Penelitian ini menggunakan metode kualitatif deskriptif dengan pendekatan induktif. Teknik pengumpulan data menggunakan metode wawancara, dokumentasi, dan observasi 
Temuan penelitian mengungkapkan bahwa Pelayanan Terpadu Satu Pintu belum efektif meningkatkan kualitas pelayanan publik di Dinas Penanaman Modal dan Pelayanan Terpadu Satu Pintu Provinsi Aceh. Adapun yang menyebabkan belum efektifnya PTSP dalam meningkatkan kualitas pelayanan publik adalah kualitas sumber daya manusia yang belum memadai, kurang lengkapnya sarana dan prasarana yang tersedia, dan pengelolaan anggaran yang belum optimal.

Kata kunci: efektivitas, PTSP, pelayanan publik

\section{PENDAHULUAN}

$\mathrm{U}$

ntukmembangun kepercayaan masyarakat ataspelayanan publikyangselamaini dinilai tidak memuaskan maka melalui Peraturan Menteri Dalam Negeri Nomor 24 Tahun 2006 tentang Pedoman Penyelenggaraan pelayanan Terpadu Satu Pintu selanjutnya disingkat PTSP merupakan kegiatan penyelenggaraan perizinan dan non perizinan yang proses pengelolaannya mulai dari tahap permohonan sampai ke tahap terbitnya dokumen yang dilakukan dalam satu tempat.

Penyederhanaan penyelenggaraan pelayanan ini ditindaklanjuti oleh Provinsi Aceh dengan dibentuknya Peraturan Gubernur Provinsi Nanggroe Aceh Darussalam Nomor 32 Tahun 2017 tentang Penyelenggaraan Pelayanan Perizinan pada Dinas Penanaman Modal dan Pelayanan Terpadu Satu Pintu Aceh.

Berdasarkan data keluhan masyarakat yang diambil dari Dokumen Dinas Penanaman Modal dan Pelayanan Terpadu Satu Pintu Provinsi Aceh, antara lain sebagai berikut.

Tabel 1. Data Keluhan Masyarakat

\begin{tabular}{lllll}
\hline \multirow{2}{*}{ No } & \multirow{2}{*}{$\begin{array}{c}\text { Keluhan } \\
\text { Masyarakat }\end{array}$} & \multicolumn{3}{c}{ Jumlah Keluhan } \\
\cline { 3 - 5 } & 2017 & $\mathbf{2 0 1 8}$ & $\mathbf{2 0 1 9}$ \\
\hline 1. & Kepastian & 20 & 25 & 26 \\
& Waktu & & & \\
2. & Kondisi SDM & 18 & 19 & 22 \\
3. & $\begin{array}{l}\text { Sarana dan } \\
\text { Prasarana }\end{array}$ & 25 & 27 & 27 \\
\hline Total & & 63 & 71 & 75 \\
\hline
\end{tabular}

Sumber: Dokumen Dinas Penanaman Modal dan
Pelayanan Terpadu Satu Pintu Provinsi Aceh, 2019

Data tabel 1 menunjukkan keluhan masyarakat antara lain, keterlambatan waktu dalam penyelesaian pengajuan permohonan berkas, proses pelayanan yang kurang efisien karena terbatasnya nomor antrean per harinya. Kurang praktisnya proses perolehan informasi karena beberapa petugas kurang menguasai informasi yang dibutuhkan masyarakat pemohon, serta terbatasnya fasilitas seperti kurangnya kursi untuk para pemohon sehingga para pemohon harus menunggu proses pelayanan sambil berdiri. Data di atas juga menunjukkan bahwa adanya peningkatan keluhan dari tahun ke tahun baik dari segi kepastian waktu, sumber daya manusia, maupun sarana dan prasarana yang terus mengalami peningkatan.

Upaya dalam meningkatkan pelayanan publik hanya akan berhasil mewujudkan perubahan yang menyeluruh apabila dilakukan secara konsisten. Hanya dengan mendorong perubahan menyeluruh dan menyentuh setiap dimensi masalah pelayanan publik, maka hal ini mampu memperbaiki tingkat kepercayaan masyarakat kepada pemerintah.

Oleh karena itu, negara dalam sistem pemerintahan menjadi landasan pelayanan masyarakat dalam memperoleh jaminan atas hak-hak ya, sehingga demikian peningkatan kualitas pelayanan akan semakin penting bagi masyarakat pengguna jasa pelayanan pemerintah.

Berdasarkan data wawancara awal yang dilakukan Peneliti kepada Kepala Dinas Penanaman Modal dan Pelayanan Terpadu Satu Pintu Provinsi Aceh dan Kepala Bidang 
Pengaduan, Kebijakan dan Pelaporan Pelayanan Dinas Penanaman Modal dan Pelayanan Terpadu Satu Pintu Provinsi Aceh didukung dengan data keluhan masyarakat terhadap pelayanan terpadu satu pintu di Dinas Penanaman Modal dan Pelayanan Terpadu Satu Pintu Provinsi Aceh terdapat berbagai kendala yang memengaruhi efektivitas pelayanan berbentuk pelayanan terpadu satu pintu di Dinas Penanaman Modal dan Pelayanan Terpadu Satu Pintu Provinsi Aceh.

\section{Identifikasi Masalah}

Berdasarkan latar belakang di atas, penelti mengidentifikasi beberapa pokok permasalahan, yaitu sebagai berikut.

1. Bertambahnya keluhan masyarakat dari tahun 2017 hingga tahun 2019.

2. Kurangnya petugas loket yang hanya berjumlah empat orang dalam melayani masyarakat yang mengajukan permohonan sehingga menyebabkan ketidakmampuan petugas loket dalam meng-handle jumlah pemohon dalam mengajukan surat perizinan dan non perizinan per harinya.

3. Tidak tersedianya pusat informasi yang terpusat menyebabkan masyarakat merasa kurang praktis dalam mendapatkan informasi.

4. Masih kurangnya ketersediaan sarana dan prasarana yang tersedia di ruang tunggu pelayanan. Seperti halnya ketidaksediaan kursi untuk para pemohon mengantre, kursi untuk masyarakat berkebutuhan khusus.

\section{Rumusan Masalah}

1. Bagaimana efektivitas penyelenggaraan pelayanan terpadu satu pintu dalam meningkatkan pelayanan publik di Dinas Penanaman Modal dan Pelayanan Terpadu Satu Pintu Provinsi Aceh dalam hal kualitas pelayanan perizinan dan non perizinan?

2. Apa saja yang menjadi kendala dalam penyelenggaraan pelayanan terpadu satu pintu dalam meningkatkan pelayanan publik di Dinas Penanaman Modal dan Pelayanan Terpadu Satu Pintu Provinsi Aceh dalam hal kualitas pelayanan perizinan dan non perizinan?

3. Apa saja upaya yang dilakukan Pemerintah dalam menyelesaikan faktor penghambat atau kendala penyelenggaraan pelayanan terpadu satu pintu dalam meningkatkan pelayanan publik di Dinas Penanaman Modal dan Pelayanan Terpadu Satu Pintu Provinsi Aceh dalam hal kualitas pelayanan perizinan dan non perizinan?

\section{Maksud Penelitian}

Dengan berpedoman pada rumusan masalah di atas, maka penelitian yang dilakukan oleh penulis bermaksud untuk mengetahui, mengumpulkan, dan mengelola data dan informasi dalam memperoleh gambaran serta pengetahuan tentang efektivitas pelayanan terpadu satu pintu dalam meningkatkan pelayanan terpadu satu pintu Provinsi Aceh.

\section{KAJIAN PUSTAKA}

\section{Efektivitas}

Efektivitas menurut Gibson, yaitu: "Effectiveness is the achievement of the goals aggreed on a joint effort. The target achievement level shows the level of effectivenesss". Gibson mengemukakan bahwa efektivitas merupakan suatu pencapaian sasaran yang telah disepakati atas usaha bersama, di mana tingkat pencapaian sasaran itu menunjukkan tingkat efektivitas. Selanjutnya Gibson menjelaskan bahwa "In relation to the effectiveness of organizational behaviour refers to the optimal relation 
between the five components; production, efficiency, satisfaction, adaptability, and development." Menurut Gibson dalam hal hubungannya dengan efektivitas perilaku keorganisasian menunjuk kepada kaitan yang optimal antara lima komponen, yaitu produksi, efisiensi, kepuasan, kemampuan adaptasi, dan pengembangan.

Pada penelitian ini, Peneliti menggunakan teori Efektivitas menurut Gibson karena Peniliti ingin mengetahui bagaimana efektivitas Pelayanan Terpadu Satu Pintu dalam meningkatkan kualitas pelayanan publik di Provinsi Aceh dengan menggunakan subvariabel yang dikemukakan oleh Gibson, antara lain sebagai berikut.

1. Produktivitas, merupakan kemampuan organisasi untuk memproduksi jumlah dan mutu output yang sesuai dengan permintaan lingkungan.

2. Efisiensi, didefinisikan sebagai angka perbandingan (rasio) antara output dan input. Kriteria jangka pendek ini memusatkan perhatian pada seluruh siklus input-proses-output.

3. Kepuasan, penyusunan konsep memperhatikan keuntungan yang diterima oleh para pesertanya maupun oleh para pelanggannya. Ukuran kepuasan meliputi sikap karyawan, pergantian karyawan, kemangkiran, keterlambatan, dan keluhan.

4. Adaptasi, adalah sampai seberapa jauh organisasi dapat menanggapi perubahan internal dan eksternal.

5. Perkembangan, organisasi wajib melakukan investasi dalam organisasi itu sendiri untuk memperluas kemampuannya untuk bertahan dalam jangka panjang. Usaha pengembangan yang biasa adalah program pelatihan bagi tenaga manajemen dan nonmanajemen, tetapi sekarang ini pengembangan organisasi telah bertambah banyak macamnya dan meliputi sejumlah pendekatan psikologis dan sosiologis.

\section{Pelayanan}

Kotler berpendapat bahwa " pelayanan merupakan setiap tindakan atau kegiatan yang dapat ditawarkan oleh satu pihak kepada pihak lain, pada dasarnya pelayanan tidak berwujud dan tidak mengakibatkan kepemilikan apa pun."

Moenir juga mengemukakan pendapatnya tentang pelayanan, yaitu “ pelayanan hakikatnya adalah serangkaian kegiatan, karena itu merupakan sebuah proses. Sebagai sebuah proses, pelayanan berlangsung secara rutin dan berkesinambungan, meliputi seluruh organisasi dalam masyarakat."

Menurut Kamus Besar Bahasa Indonesia, pelayanan merupakan perihal atau cara melayani, usaha melayani kebutuhan orang lain.

\section{Pelayanan Terpadu Satu Pintu oleh Dinas Penanaman Modal dan Pelayanan Terpadu Satu Pintu}

Berdasarkan Peraturan Menteri Dalam Negeri Nomor 24 Tahun 2006 tentang Pedoman Penyelenggaraan Pelayanan Terpadu Satu Pintu, disebutkan bahwa penyelenggaraan pelayanan terpadu satu pintu adalah kegiatan penyelenggaraan perizinan dan non perizinan yang proses pengelolaannya mulai dari tahap pemohon sampai ke tahap terbitnya dokumen dalam satu tempat.

Menindaklanjuti peraturan menteri dalam negeri di atas, Pemerintah Aceh membentuk Peraturan Gubernur Aceh Nomor 32 Tahun 2017 tentang Penyelenggaraan Pelayanan Perizinan dan Non-perizinan Pada Dinas Penanaman Modal dan Pelayanan 
Terpadu Satu Pintu Aceh. Pada peraturan gubernur ini, jenis perizinan dan nonperizinan yang menjadi kewenangan Dinas Penanaman Modal dan Pelayanan Terpadu Satu Pintu Aceh pada Pasal 7, yaitu sebagai berikut.

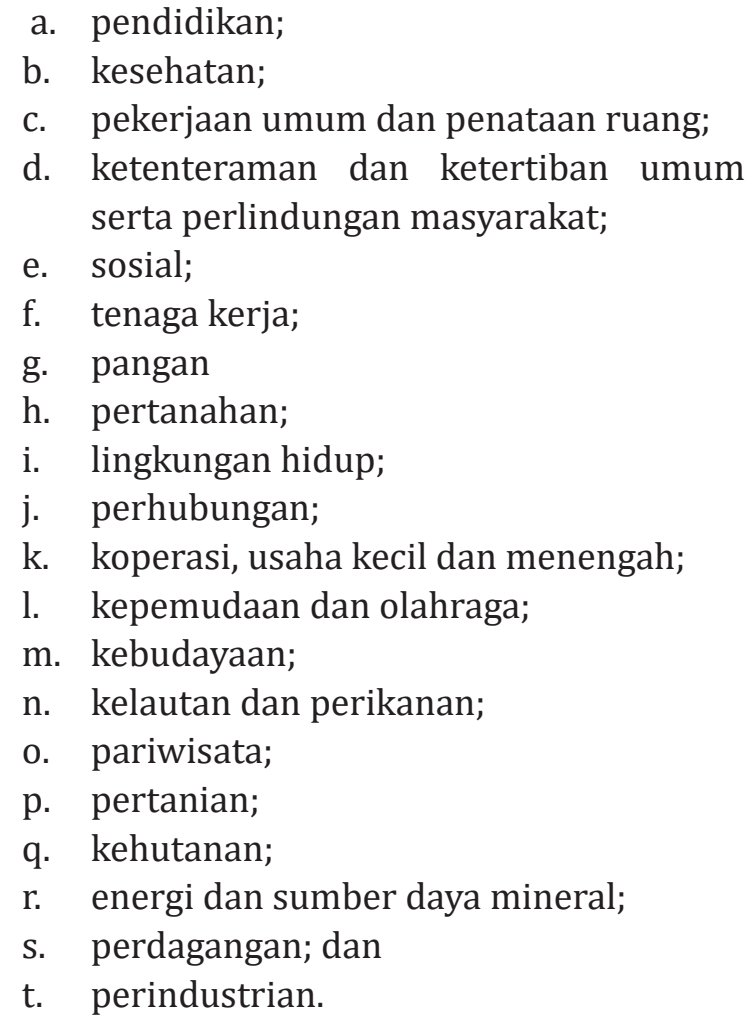

\section{Kualitas Pelayanan Publik}

Kualitas pelayanan menurut Yogi, yaitu: "sebagai suatu kondisi dinamis yang berhubungan dengan produk, jasa, manusia, proses dan lingkungan yang memenuhi atau melebihi harapan". Oleh karenanya kualitas pelayanan berhubungan dengan pemenuhan harapan atau kebutuhan pelanggan. Penilaian terhadap kualitas pelayanan ini dapat dilihat dari beberapa sudut pandang yang berbeda, misalnya dari segi product based, di mana kualitas pelayanan didefinisikan sebagai suatu fungsi yang spesifik, dengan variabel pengukuran yang berbeda terhadap karakteristik produknya; user based, berhubungan dengan kegunaan atau kepuasan atas harga.
Kotler mendefinisikan kualitas pelayanan, yaitu: "the extent of discrepancy between customers expectations or desires and their perception".

Maksudnya adalah kualitas pelayanan yang diterima konsumen dinyatakan dalam besarnya ukuran ketidaksesuaian antara harapan atau keinginan konsumen dengan tingkat persepsi mereka.

Kotler juga berpendapat untuk mengukur kualitas pelayanan dapat digunakan indikator sebagai berikut.

1. Tangibles, yaitu fasilitas fisik, peralatan, pegawai, dan fasilitas-fasilitas komunikasi yang dimiliki oleh penyedia layanan;

2. Reliability, kehandalan adalah kemampuan untuk memberikan pelayanan yang dijanjikan dengan tepat (accurately) dan kemampuan untuk dipercaya (depandably), memberikan jasa secara tepat waktu (ontime), dengan cara yang sama sesuai dengan jadwal yang telah dijanjikan dan tanpa melakukan kesalahan setiap kali;

3. Responsiveness, atau daya tanggap, yaitu kemampuan atau keinginan para petugas untuk membantu dan memberikan jasa yang dibutuhkan penerima layanan. Membiarkan penerima layanan menunggu, terutama tanpa alasan yang jelas sehingga menimbulkan kesan negatif yang tidak seharusnya terjadi. Kecuali jika kesalahan ini ditanggapi dengan cepat, maka bisa menjadi suatu hal yang berkesan bagi konsumen.

4. Assurance, jaminan kepastian, yaitu pengetahuan, kesopanan, dan kemampuan para petugas penyedia pelayanan dalam memberikan kepercayaan kepada pengguna layanan;

5. Emphaty, empati adalah kemampuan memberikan perhatian kepada pengguna layanan secara individual 
yang meliputi sikap kontak petugas maupun perusahaan untuk memahami kebutuhan maupun kualitas penerima layanan komunikasi yang baik, perhatian pribadi, kemudahan dalam melakukan komunikasi atau hubungan.
Pada Penelitian ini, untuk mengukur kualitas pelayanan publik terhadap penyelenggaraan pelayanan terpadu satu pintu, Peneliti akan menggunakan teori Kotler, yaitu mengukur kualitas pelayanan publik dengan indikator yang telah dipaparkan di atas.

\section{Kerangka Pemikiran}

1. UU Nomor 25 Tahun 2009 tentang Pelayanan Publik

2. Peraturan Gubernur Aceh Nomor 32 Tahun 2017 tentang Penyelenggaraan Pelayanan Perizinan dan Nonperizinan pada Dinas Penanaman Modal dan Pelayanan Terpadu Satu Pintu

$\downarrow$

Kewenangan Dinas Penanaman Modal dan Pelayanan Terpadu Satu Pintu dalam berdasarkan Pergub Aceh Nomor 32 Tahun 2017 yaitu :

Kewenangan untuk melayani dan menandatangani 20 bidang

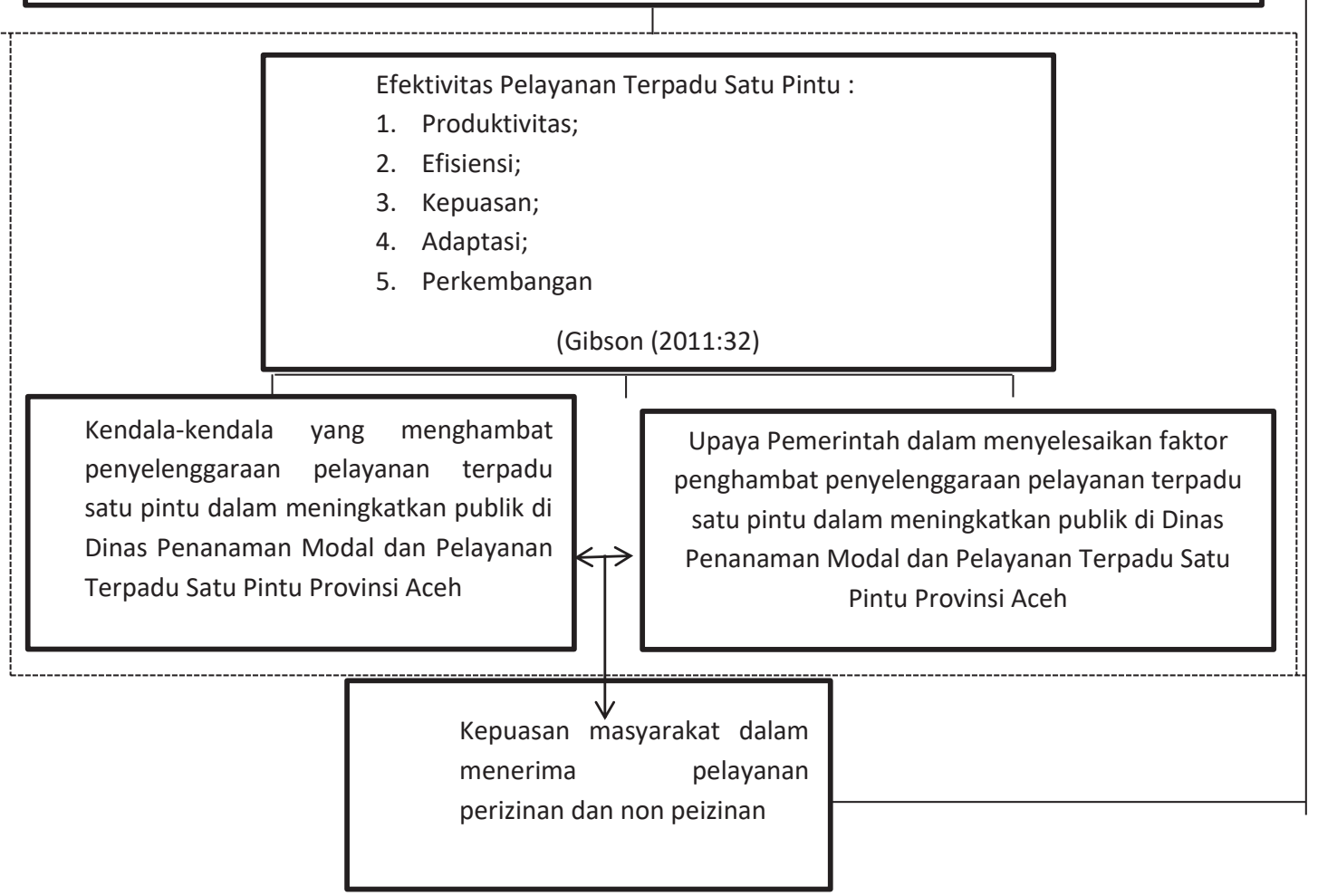

Keterangan :

------- : Lingkup Penelitian

Sumber : Diolah Oleh Peneliti, 2019

\section{Gambar 1}

Kerangka Pemikiran 


\section{METODE PENELITIAN}

Tabel 2 Kerangka Konseptual Penelitian

\begin{tabular}{|c|c|c|c|}
\hline Konsep & Dimensi & Indikator & Kriteria \\
\hline \multirow{11}{*}{$\begin{array}{l}\text { Gibson } \\
\left(\begin{array}{lll}2 & 011 \\
27\end{array}\right)\end{array}$} & Produktivitas & - Proses Kerja & - Memenuhi standar Pergub No. 32/2017 \\
\hline & & - Hasil Kerja & - Memenuhi standar Pergub No. 32/2017 \\
\hline & Efisiensi & - Penghematan & - Penggunaan Anggaran (APBD) \\
\hline & & - Pencapaian Tujuan & - Memenuhi standar Pergub No. 32/2017 \\
\hline & Kepuasan & - Ketepatan waktu & - Kesesuain waktu yang telah ditetapkan \\
\hline & & - Tepat Hasil & - Pencapaian Hasil Yang Telah Ditargetkan \\
\hline & & - Adil & - Pengakuan Masyarakat \\
\hline & & - Keluhan & - Pengaduan Masyarakat \\
\hline & Adaptasi & - Ruang Perubahan & - Ketanggapan Sumber Daya \\
\hline & & - Inovasi & - Pembaharuan \\
\hline & Perkembangan & $\begin{array}{ll}\text { - } & \text { Daya } \\
& \text { Organisasi }\end{array}$ & $\begin{array}{l}\text { - Kemampuan } \\
\text { masalah }\end{array}$ \\
\hline
\end{tabular}

Sumber: Diolah oleh Peneliti. 2019 (Gibson (2011:27)

Pada penelitian inipeneliti menggunakan desain penelitian, yaitu penelitian kualitatif dengan metode deskriptif pendekatan induktif. Kerangka konseptual penelitian seperti tampak pada tabel 2 di atas.

\section{HASIL PENELITIAN DAN PEMBAHASAN}

Berdasarkan penelitian yang telah dilakukan oleh Peneliti, bahwa pelayanan terpadu satu pintu di Dinas Penanaman Modal dan Pelayanan Terpadu Satu Pintu Provinsi Aceh belum mampu meningkatkan kualitas pelayanan publik. Hal ini terbukti dengan belum terpenuhinya setiap dimensi yang menjadi landasan dalam penelitian ini, baik dari dimensi produktivitas, efisiensi, kepuasan, adaptasi, maupun perkembangan.

Belum efektifnya pelayanan terpadu satu pintu dalam meningkatkan kualitas pelayanan publik di Dinas Penanaman Modal dan Pelayanan Terpadu Satu Pintu Provinsi Aceh disebabkan oleh banyaknya kendala sehingga membuat dimensi-dimensi di atas tidak dapat terpenuhi.

\section{Kendala dalam Penyelenggaraan Pela- yanan Terpadu Satu Pintu}

Adapun kendala-kendala yang menyebabkan belum efektifnya penyelenggaraan pelayanan terpadu satu pintu dalam meningkatkan pelayanan publik di Dinas Penanaman Modal dan Pelayanan Terpadu Satu Pintu Provinsi Aceh adalah kurangnya kualitas sumber daya manusia, sarana dan prasarana yang belum memadai, dan pengelolaan anggaran yang belum optimal.

\section{Upaya Pemerintah dalam Menyele- saikan Faktor Penghambat Penye- lenggaraan Pelayanan Terpadu}

1. Dinas Penanaman Modal dan Pelayanan Terpadu Satu Pintu Provinsi Aceh melakukan peningkatan kualitas sumber daya manusia melalui pelatihan peningkatan secara berkala guna menggali kemampuan dalam penyelenggaraan pelayanan terpadu satu pintu dalam meningkatkan pelayanan publik di Dinas Penanaman Modal dan Pelayanan Terpadu Satu Pintu Provinsi Aceh. 
2. Dinas Penanaman Modal dan Pelayanan Terpadu Satu Pintu Provinsi Aceh melakukan pengelolaan anggaran penyelenggaraan pelayanan terpadu satu pintu di Dinas Penanaman Modal dan Pelayanan Terpadu Satu Pintu Provinsi Aceh yang harus dioptimalkan sehingga tepat guna dan tepat sasaran dengan mempekerjakan pengelola anggaran yang cakap dan andal.

3. Dinas Penanaman Modal dan Pelayanan Terpadu Satu Pintu Provinsi Aceh melakukan pengoptimalan penyediaan sarana dan prasarana penyelenggaraan pelayanan terpadu satu pintu dalam meningkatkan pelayanan publik di Dinas Penanaman Modal dan Pelayanan Terpadu Satu Pintu Provinsi Aceh

\section{SIMPULAN}

Berdasarkan hasil penelitian yang dilakukan oleh Peneliti tentang efektivitas pelayanan terpadu satu pintu dalam meningkatkan kualitas pelayanan terpadu satu pintu di Dinas Penanaman Modal dan Pelayanan Terpadu Satu Pintu Provinsi Aceh dapat disimpulkan sebagai berikut.

1. Efektivitas pelayanan terpadu satu pintu dalam meningkatkan kualitas pelayanan publik di Dinas Penanaman Modal dan Pelayanan Terpadu Satu Pintu Provinsi Aceh belum berjalan dengan baik. Hal ini dibuktikan dengan masih banyaknya kendala yang ada.

2. Terdapat sejumlah faktor yang menyebabkan belum efektifnya pelayanan terpadu satu pintu dalam meningkatkan kualitas pelayanan publik di Dinas Penanaman Modal dan Pelayan Terpadu Satu Pintu Provinsi Aceh, yaitu kualitas sumber daya manusia yang belum memadai, sarana dan prasarana yang belum memadai, dan pengelolaan anggaran yang belum optimal.
3. Upaya yang dilakukan pemerintah dalam menyelesaikan faktor penghambat belum efektifnya pelayanan terpadu satu pintu dalam meningkatkan kualitas pelayanan publik di Dinas Penanaman Modal dan Pelayanan Terpadu Satu Pintu Provinsi Aceh sebagai berikut.

a. Memberikan pelatihan kepada penyelenggara pelayanan terpadu satu pintu

b. Melakukan pengelolaan anggaran yang harus tepat guna dan tepat sasaran.

c. Mengoptimalkan sarana dan prasarana penyelenggara pelayanan terpadu satu pintu dengan permendagri Nomor 7 Tahun 2006 tentang standardisasi sarana dan prasarana kerja pemerintahan daerah

\section{SARAN}

Berdasarkan simpulan di atas maka peneliti memberikan saran di antaranya adalah:

1. Agar mencapai efektivitas pelayanan terpadu satu pintu dalam meningkatkan kualitas pelayanan publik di Dinas Penanaman Modal dan Pelayanan Terpadu Satu Pintu Provinsi Aceh. Pemerintah bias terus mencoba berkomitmen penuh dalam mengefektifkan penyelenggaraan pelayanan terpadu satu pintu.

2. Pemerintah Aceh khususnya Dinas Penanaman Modal dan Pelayanan Terpadu Satu Pintu Provinsi Aceh dapat mencoba mengoptimalkan pengelolaan anggaran yang harus tepat guna dan tepat sasaran dengan mempekerjakan pengelola yang ahli dalam bidangnya.

3. Dinas Penanaman Modal dan Pelayanan Terpadu Satu Pintu dapat lebih memperhatikan kekurangan fasilitas penyelenggaraan pelayanan terpadu 
satu pintu dan berkomitmen penuh untuk memperbaiki kekurangan tersebut.

\section{DAFTAR PUSTAKA}

Arikunto, Suharsimi. 2015. Prosedur Penelitian: Suatu Pendekatan Praktik, Edisi Revisi VI. Jakarta: PT. Rineka Cipta.

Bruce Lawrence Berg. 2017. Qualitative Research Method For The Social Sciences Edisi Terjemahan. Bandung: Unpad Press

Creswell, John W. 2017. Educational research: Planning, conducting, and evaluating quantitative and qualitative research (edisi ke-4) Upper Saddle River. NJ: Merill.

Davis, Keith, dan Newstorm. 1996 Perilaku Dalam Organisasi Edisi Tujuh. Jakarta: Erlangga.

Dunn. 2019. Analisis kebijakan publik jilid 2 edisi terjemahan. Yogyakarta: UGM Press

Dwiyanto, Agus. 2017. Reformasi Birokrasi Publik di Indonesia. Yogyakarta: UGM Press.

Gibson, Ivancevich, Donnelly. 2011. Organisasi: Perilaku, Struktur, Proses, Jilid 2. Edisi Terjemahan. Jakarta: Erlangga.

Given, M. Lisa. 2015 The Sage Encyclopedia of qualitative reserach methods. Charles Sturt University: Australia.

H. A. S Moenir. 2016. Manajemen Pelayanan Umum. Jakarta: PT. Bumi Aksara.

Heizer, Jay and Render Barry. 2015. Manajemen Operasi: Manajemen Keberlangsungan dan Rantai Pasokan, Edisi 11. Jakarta: Salemba Empat.

Husain Usman dan Purnomo Setiady Akbar. 2014. Metodologi Penelitian Sosial, Jakarta: Bumi Aksara

Indrawijaya, adam Ibrahim. 2015. Teori, Perilaku, dan Budaya Organisasi. Bandung: PT. Refika Aditama.

Jonathan Sarwono. 2016. Metode Penelitian Kuantitatif dan Kualitatif. Yogyakarta: Graha Ilmu

Kotler, Philip and Kevin Lane Keller. 2016, Marketing Management. Edisi Terjemahan. Jakarta: Jurnal UI
Longkutoy, John J. 2015. Pengenalan Komputer. Jakarta: Mutiara Sumber Widya.

Lukman, Sampara. 1999. Manajemen Kualitas Pelayanan. Jakarta: STIA LAN Press.

Moh. Nazir. 2015. Metodologi penelitian. Gramedia: Bandung

Moleong, L. J 2016. Metode Penelitian Kualitatif Edisi Revisi. Bandung: PT Remaja Rosdakarya

Muchlis Hamdi dan Siti Ismaryati. 2014. Metodelogi Penelitian Administrasi, Tangerang Selatan: Universitas Terbuka Press

Nicholas Walliman. 2019. Social Research Methods, London: Sage Publication

Pamudji. 1994. Public Relation dalam Teori dan Praktik. Jakarta: PT. Gramedia.

Robert E. Stake, 2010. qualitative research. New York: Guilford Press

Sinambela., Lijan Poltak. 217. Reformasi Pelayanan Publik. Jakarta: PT Bumi Aksara.

Sedarmayanti. 2017. Sumber daya manusia dan Produktivitas Kerja. Bandung: Mandar Maju.

Steers, Richard. 2017. Efektivitas Organisasi. Cetakan Kedua. Jakarta: Erlangga.

Sugiyono. 2016 Metode Penelitian Kuantitatif, Kualitatif, dan R\&D. Bandung: Alfabeta

Sunyoto. 2016. Metodologi Penelitian Akuntansi. Yogyakarta: Caps

Sutabri, Tata. 2016. Analisis Sistem Informasi. Yogyakarta: Andi

Widodo, Joko. 2016. Good Governance Telaah dari Dimensi Akuntabilitas, Kontrol Birokrasi Pada Era Desentralisasi dan Otonomi Daerah. Surabaya: Insan Cendekia.

Yogi, S dan Ikhsan, Muhammad. 2016. Standar Pelayanan Publik di Daerah, Handbook Manajemen Pemerintahan Daerah. Jakarta: PKKOD-LAN.

Zeithaml, Parasuraman, and Berry. 1990. Delivering Quality Service. (New York: The Free Pass. 


\section{Peraturan Perundang-Undangan}

Kepmenpan No 63/KEP/m. PAN/7/2003 tentang Pedoman Umum Penyelenggaraan Pelayanan Publik

Permendagri Nomor 24 Tahun 2006 tentang Pedoman Penyelenggaraan Pelayanan Terpadu Satu Pintu

UU Nomor 25 Tahun 2009 tentang Pelayanan Publik

\section{Tesis dan Jurnal}

Dwi Bagus Yoga, Priyanto Susiloadi. 2017: Manajemen Pelayanan Terpadu Satu Pintu pada Dinas Penanaman Modal dan Pelayanan Terpadu Satu Pintu dalam Pelayanan Perizinan di Kota Surakarta. Surabaya: Jurnal USM

Fauzan, Rizki. 2009. Efektivitas Kantor Pelayanan Perizinan Terpadu Satu Pintu (KPPTSP) Dalam Memberikan Izin Mendirikan Bangunan (IMB) Di Kota Banda Aceh. Jakarta: Institut Pemerintahan Dalam Negeri

Hakim, L., Basuki, J., Soemartono, T., Kusworo, K. (2019) Licensing Services Innovation Establishing Buildings in One Stop Integrated Services in North Jakarta. International Journal for Educational and Vocational Studies, 1 (7), 667-675

Hidayat Fatah, Sutomo, Bagus Sigit, 2018. Implementasi Pelayanan Terpadu Satu Pintu (PTSP) Banyuwangi: Jurnal Unmuhjember

Haida, Achmad Nur, Choirul Saleh, Romula Adio No. 2010. Pelayanan Terpadu Satu Pintu sebagai Upaya Peningkatan Pelayanan Perizinan. Malang: Jurnal Unibraw
Rengifurwamin. Z. A. 2019. Analysis of Public Service Bureaucracy Reform at the OneStop Investment and Integrated Services office, Maluku Province. International Journal of Science and Society

Sama Abdul Wahab, Muchlis R. Ludin, Billy Tunas, James Tangkudung. 2019 Evaluation of One Stop Integrated Service of Employment Placement and Protection Programs of Gianyar RegencyBali. International. Journal of Innovative Technology and Exploring Engineering (IJITEE)

Saputra, Angga Dwi Saputra, Arif Budy Pratama, Eny Boedi Orbawati. 2020 Public Service Transformation. A Case Study of Online Single Submission at The Office of Investment and Integrated Services Magelang Municipality. Jurnal Ilmiah Ilmu Administrasi Publik: Jurnal Pemikiran dan Penelitian Administrasi Publik

Sari, Puteri Vuspa. 2010. Kualitas Pelayanan Perizinan Sektor Perubahan Pada Kantor PTSP Di Kabupaten Tebo. Jakarta: Institut Pemerintahan Dalam Negeri.

Yusriadi, 2017. Bureaucratic Reform in Public Service: A Case Study on the One StopIntegrated Service. Mediterranean Journal of Social Sciences

\section{Internet}

https: / / mediaindonesia.com / read / detail/247783-ombudsman-ungkapkualitas-pelayanan-publik. (22 Desember 2019) 